\title{
THE INFLUENCE OF CORPORATE SOCIAL RESPONSIBILITY AND AUDIT COMMITTEE ON COMPANY'S VALUE
}

\author{
Sari Rafika*, Wahyudi Tertiarto, Isnurhadi \\ Sriwijaya University, Palembang, Indonesia \\ *E-mail: vicha.chu@gmail.com \\ ORCID: 0000-0002-0686-7508
}

\begin{abstract}
The aim of this research was to find out to what extent the influence of disclosure of Corporate Social Responsibility and the number of audit committees on the corporate value of the companies listed on the Indonesia Stock Exchange during 2016 period. The data analysis method used was multiple linear regressions. This method was chosen since the reference showed that there was a match between the analysis tool and the variables under the research. The data sampling of the research applied random sampling using solvin formula with the significance level of 5 percent so that the number of samples was 191 companies which were then taken randomly. The random sampling method was chosen because it was in accordance with the method of multiple regression analysis. Corporate Social Responsibility variable had a significant influence on the Corporate Value of the companies listed on the Indonesia Stock Exchange. The variable of Audit Committee had an insignificant influence on the Corporate Value of the companies listed on the Indonesia Stock Exchange. The variable of Market Capitalization did not moderate the relationship of Corporate Social Responsibility to Corporate Value. The variable of Market Capitalization did not moderate the relationship of audit committee to Corporate Value.
\end{abstract}

\section{KEY WORDS}

Corporate social responsibility, auditory committee, company's value.

The current accountancy development has found many social theories in which a company do not more just graded based on its assets but also how its social responsibility programs. As matter of fact, the company development should be in line with the level of either natural reseource exploitation or human reseource employing, dealing with this, there are many company take path development on what is known as corporate social responsibility (Bayu et al., 2015).

Every company precisely competes to get high value because it shows the high prosperity of its shareholders. Thus, they will invest their financial capital in the company (Cretu and Brodie, 2007). The increasing of company value is a periodical purpose which will higher its market stock price to persuade investors (Anggraeni, 2013).

The global competition which continuously increases causes companies to improve their value in many sectors to meet inventors' interest. Hence, company's value becomes very important to reflect its performance affecting investors' perception toward a company. The increasing of company's value gives the positive sign for investors to invest more in a company. It also will pull out investors' perspective concerning company's performance and its prospect in the future (Goold et.al, 1994)

Every company does not only aim to maximize its profit but also to perform social responsibility and prosperity. Thus, the company will not only have a responsibility to its shareholders but also stakeholders (Freeman, 2004). The better a company develops its value, the higher natural source exploitation and social society. This causes the existence of positive awareness to cover the negative impacts. Hence, the most company applies Corporate Social Responsibility (Bayu et.al, 2015).

Corporate Social Responsibility (CSR) influences the increasing company's value because it has the moral responsibility of a company regarding the strategic stakeholders (Mc Williams and Siegel, 2000). Expressing of Corporate social responsibility is a 
communication process of social and environment from economic activity toward specific community and general society (Matten and Moon, 2004). It extends company's responsibility to provide a report concerning the financial to the shareholders. This extends is created through company's responsibility which is more than only collecting profits (Putri et.al, 2016).

Commonly, a company implemented CSR will disclose its implementation. CSR expressing is conducted through social reporting disclosure in the financial report. This disclosure is important for finance reporter to analyze the company's attention and social responsibility in performing their business (Gey et.al, 1995). CSR expressing is hoped to give positive influences toward the investors to take more attention in the social aspect. Applying CSR gives many benefits, such pulling out costumers' and investors' interest (Tai and Chuang, 2014).

The auditory committee has an important rule to keep company's accountability. It supervises the financial report system and internal-external auditory to avoid asymmetry information (Klein, 2002). The increasing of auditory committee members will influence its independence which will affect the quality of company's financial report (Carcello et.al, 2000). Thus, the auditory committee is hoped to improve company's value and to help the implementation of Good Corporate Government (Anggraini, 2013).

Bigger company will have more public demand rather than the smaller company. Further, a bigger company will inform widely about their product to decrease the outcome. This action is done due to the market and shareholdings' demand. The development of a company will definitely increase the influence of auditory committee toward the company's value.

The research problem offered in this study is that how expression of corporate social responsibility and auditory committee on company's value in The Indonesia Stock Exchange (IDX) along 2016.

\section{METHODS OF RESEARCH}

This study applies double linear regression method. This method is applied because the references show the existence of appropriateness between the analytical tool and research variables. In addition, the data are analyzed and tested using SPPS, including residual, classical assumption testing, and hypothesis testing. The participant of this study is the whole companies listed in the IDX. The characteristics of the participant are: (1) the company listed in the IDX in 2016, (2) The company which already published the annual report of 2016, and (3) The company who has positive Price Earnings Ratio (PER).

Table 1 - The categorization of research participant

\begin{tabular}{ll}
\hline Note & Amount \\
\hline The total of companies registered until 2016 & 529 \\
\hline The companies that have not publish the annual report of 2016 & $(51)$ \\
\hline The companies that have negative Perusahaan EPS & $(114)$ \\
\hline Total of participant & 364 \\
\hline
\end{tabular}

From the total amount of the participant, the sample selection applies random sampling. From the random sampling, the participants chosen are 191 companies.

\section{RESULTS OF STUDY}

The hypothesis testing is done after statistical analysis toward the data obtained previously. The following point is the equality of regression.

$$
Y=a+b_{1} C S R+b_{2} A C+\varepsilon_{1}
$$


The hypothesis result on equality of regression 1 has been tested through SPSS program. The test provided such below.

F-Test. This test have been conducted to observe the how the expression of corporate social responsibility and auditory committee simultaneously influence company's value (PER) registered in Indonesia Stock Exchange. The result of the test is seen in Table 2.

Table 2 - F-Test Result

ANOVA $^{\mathrm{b}}$

\begin{tabular}{lllllll}
\hline Model & Sum of Squares & Df & Mean Square & F & Sig. \\
\hline 1 & 5.958 & 2 & 2.979 & 32.242 & $.000^{\mathrm{a}}$ \\
\cline { 2 - 6 } & 17.370 & 188 & .092 & & \\
\cline { 2 - 5 } & 23.328 & 190 & & & \\
\hline Total & & & & & & \\
\hline
\end{tabular}

a. Predictors: (Constant), Auditory Committee, Corporate Social Responsibility

b. Dependent Variable: Company's value

From the table above, it is seen that $F_{\text {count }}$ is 32.242 with 0.000 Sig. The hypothesis test in this study is comparing $F_{\text {account }}$ score and $F_{\text {table. }} F_{\text {table }}$ is based on dfl $=$ numerator's degree is 2 , df2 = denominator's degree is 191 and the significant degree is $5 \%$. Thus, the score of $F_{\text {table }}$ is 3.043. Hence, $F_{\text {count }}$ is 32.242 higher than $F_{\text {table }}$ which is 3.043 . This means the independent variables - corporate social responsibility and auditory committee influence simultaneously to dependent variable - company's value in Indonesia Stock Exchange.

$T$-Test. This test have been conducted to observe the influence of CSR and auditory committee partially to company's value (PER) registered in the IDX. The result of the test is seen in Table 3.

Table 3 - T-Test Result

Coefficients $^{a}$

\begin{tabular}{llll}
\hline Model & (Constant) & $\mathrm{t}$ & Sig \\
\cline { 2 - 4 } & Corporate Social Responsibility & 8.007 & .000 \\
\cline { 2 - 5 } & Auditory Committee & 8.012 & .000 \\
\hline
\end{tabular}

a. Dependent Variable: Company's value

The hypothesis testing of this study is by comparing the score of $T_{\text {count }}$ and $T_{\text {table. }} T_{\text {table }}$ score is based on ( $d f=n-2) d f=191-2=189$ with significant degree $5 \%$ so that the score of $T_{\text {table }}$ is 1.973. In table 3 above, the score $T_{\text {count }}$ from each variable in regression 1 equality can be explained that CSR significantly influences to company's value shown by the score of $\mathrm{T}_{\text {count }}$ which is 8.012 higher that $\mathrm{T}_{\text {table }}$ which is 1.972 . Meanwhile, the auditory committee does not significantly influence company's value shown by the score of $T_{\text {count }}$ is lower than $T_{\text {table. }}$.

Regression 2 Equality. The equality of regression 2 is tested through the residual result of hypothesis as seen in Table 4.

Table 4 - The hypothesis result by Residual Test

Coefficients $^{a}$

\begin{tabular}{llllll}
\hline \multirow{2}{*}{ Model } & \multicolumn{2}{l}{ Un-standardized Coefficients } & Standardized Coefficients & S & Sig. \\
\cline { 2 - 6 } & $\mathrm{B}$ & Std. Error & Beta & 4.068 & .000 \\
\hline 1 (Constant) & .427 & .105 & & 1.536 & .126 \\
\hline Company's value & .129 &. s084 & .111 & 1.56 \\
\hline
\end{tabular}

a. Dependent Variable: Res CSR_MV

In the residual test, if the value of coefficient $b_{1}$ is significant and negative, the capitalism market variable can be concluded as moderator variable that influences CSR and 
company's value. Based on the table 4 , the value of $b_{1}$ is positive and not significant so the regression 2 with the residual test can be concluded that market capitalism is not moderator variable between CSR and company's value.

Regression 3 equality. In the equality of regression 3, the hypothesis is tested with residual test a seen in Table 5.

Table 5 - The hypothesis result by Residual Test

Coefficients $^{a}$

\begin{tabular}{llllll}
\hline \multirow{2}{*}{ Model } & \multicolumn{2}{l}{ Unstandardized Coefficients } & Standardized Coefficients & \multirow{2}{*}{$\mathrm{t}$} & \multirow{2}{*}{ Sig. } \\
\cline { 2 - 7 } & $\mathrm{B}$ & Std. Error & Beta & 5.348 & .000 \\
\hline 1 (Constant) & .647 & .121 & -.003 & -.042 & .966 \\
\hline Company's value & -.004 & .097 & &
\end{tabular}

a. Dependent Variable: Res AC_MV

In the residual test, if the value of coefficient $b_{1}$ is significant and negative, the capitalism market variable can be concluded as moderator variable that links auditory committee and company's value. Based on table 5 , the value of $b_{1}$ is negative but not significant so the regression 3 with the residual test can be concluded that market capitalism is not moderator variable between auditory committee and company's value.

\section{DISCUSSION OF RESULTS}

The expression of CSR and AC on company's value. The disclosure of (CSR) is at the recognition root of business as a part of society which is potential to make a positive contribution to achieve social goals and aspirations (Jones and Comfort, 2005). Based on the hypothesis result testing, CSR and the auditory committee have positive and significant which simultaneously influence the company's value. Some other studies have investigated audit committee relations and financial reporting quality. Some others tend to support the existence of audit committees as the improvement of financial reporting quality (Client, 2001; De Fond and Jiambalvo, 1991). The tests use the FSCM and CRSM methods which show similar results that the profit of company applied audit committee is statistically greater than those that do not form an audit committee.

The expression of CSR on company's value. Based the result of T-test, CSR partially influences company's value. It is shown with 8.012 count which is higher than $t_{\text {table }}, 1.973$. In fact, investors view a company in Indonesia by considering corporate social responsibility implementation. In 2016, this fact interests other organizations because the report displays various items including future company performance and company's care to the social environment. Latupono and Andayani's (2016) observed on 30 companies' report in 2009 to 2011 using CSR. Their study creates conclusions, such as (1) CSR significantly influence company's value positively. It shows that the higher CSR disclosure, the more positive the stakeholders participate in sharing their composite, and (2) good corporate governance can influence the relation between CSR and company's value. This means the higher good corporate governance, the higher potential chance to improve the company's value.

The Expression of AC on company's value. Based on the result of T-test, the auditory committee does not influence company's value shown by the value of $t_{\text {count }}-1.173$ which is lower than $t_{\text {table }}-1.972$. Based on the agency, the existence of auditory committee can solve investors' conflict with the management. On the contrary, the result of this study test shows that auditory committee has no influence company's value significantly. That case is caused by the auditory committee in Indonesia does not pull out investor's interest. It is because the amount of auditory committee in Indonesia has been well-regulated by The Indonesian Regulatory Authority for the Indonesian Capital Market No. Kep- 643/BL/2012 about implementation guide of the auditory committee so that investors consider that a company will the rules. 
The moderation of company size toward CSR on company's value. Based on the residual test results on both company size equality cannot moderate the influence of CSR with corporate value. Although the agency and legitimacy theory based that larger companies will have greater CSR disclosure, the research results show insignificant value, instead. This is because the measurement indicators through GRI 4 do not limit the enforcement between large and small companies. In fact, companies with large market capitalization have a good image so that CSR disclosure does not become the main focus of investors' valuation of company value, while for small companies despite wider disclosure of CSR to attract investors, business risks will have higher consideration for investors. This result is inconsistent with the research of Muliani et.al (2014) that shows that CSR is able to moderate the financial performance of the company's value positively. It means the more CSR disclosure, the higher the financial performance and the impact on company's high value.

The moderation of company size on the AC on company's value. Based on the Residual Test, three companies size equality cannot moderate the influence of auditory committee on the company's value. This is because the number of the auditory committees has been regulated in The Indonesian Regulatory Authority for the Indonesian Capital Market No. Kep- 643/BL/2012 dated December 7, 2012. This causes the size of large and small companies generally only follow the standard rules based on observations from the existing data on the company report. The average company only has 3 auditory committee members based on the minimum amount regulated by The Indonesian Regulatory Authority for the Indonesian Capital Market No. Kep- 643/BL/2012. It is different from Rahayu et.al (2010) who indicates that the quality of auditory committee affects the quality of financial report. The expertise of audit committees in finance significantly increases the persistence and predictability of profits. The amount of the auditory committee is significantly positive for persistence and negatively affects the profit and conservatism predictability. The number of auditory committee members' in meetings also significantly and positively affects persistence, predictability and conservatism.

\section{CONCLUSION}

The expression of Corporate social responsibility (CSR) significantly influence toward company's value in Indonesia Stock Exchange (IDX)

The Wexpression of auditory committee does not give significant influence toward company's value in Indonesia Stock exchange.

Market capitalization does not moderate corporate social responsibility and auditory committee relation to company's value.

\section{REFERENCES}

1. Anggraini, D. (2013). Pengaruh Good Corporate Governance, 2, 1-14.

2. Bayu, A. N., Putra, D., \& Wirakusuma, M. G. (2015). Pengaruh Pengungkapan Corporate Social Responsibility Pada Nilai Perusahaan Dengan Profitabilitas Sebagai Pemoderasi. Jurnal Akuntansi Universitas Udayana, 13(2), 2302-8556.

3. Carcello, J. V., \& Neal, T. L. (2000). Audit committee composition and auditor reporting. The Accounting Review, 75(4), 453-467.

4. Cretu, A. E., \& Brodie, R. J. (2007). The influence of brand image and company reputation where manufacturers market to small firms: A customer value perspective. Industrial Marketing Management, 36(2), 230-240.

5. De Fond, M. L. dan Jiambalvo, J. (1994). Debt Convenant Violation and Manipulation of Accruals. Journal of Accounting\&Ecconomics, 17, 145-176.

6. Freeman, R. E., Wicks, A. C., \& Parmar, B. (2004). Stakeholder theory and "the corporate objective revisited". Organization science, 15(3), 364-369.

7. Goold, M., Campbell, A., \& Alexander, M. (1994). Corporate-level strategy: Creating value in the multibusiness company. Wiley. 
8. Jones, P., \& Comfort, D. (2005). Corporate Social Responsibility and The UK's Top Ten Retailers. International Journal of Retail Distribution Management, 33(12), 882-892.

9. Klein, A. (2002). Audit committee, board of director characteristics, and earnings management. Journal of accounting and economics, 33(3), 375-400.

10. Latupono, S. S., \& Andayani, A. (2016). Pengaruh Corporate Social Responsibility Terhadap Nilai Perusahaan: Good Corporate Governance Variabel Moderating. Jurnal IImu dan Riset Akuntansi, 4(8).

11. Matten, D., \& Moon, J. (2004). Corporate social responsibility. Journal of business Ethics, 54(4), 323-337.

12. Mc Williams, A., \& Siegel, D. (2000). Corporate social responsibility and financial performance: correlation or misspecification?. Strategic Management Journal, 21(5), 603609.

13. Muliani, L. E., Yuniarta, G. A., \& Sinarwati, N. K. (2014). Pengaruh Kinerja Keuangan Terhadap Nilai Perusahaan Dengan Pengungkapan Corporate Social Responcibility Dan Good Corporate Governance Sebagai Variabel Pemoderasi. JIMAT (Jurnal Ilmiah Mahasiswa Akuntansi) Undiksha, 2(1).

14. Rahayu, S., Rahayu, S., \& Andri, A. (2010). Pengaruh Kinerja Keuangan Terhadap Nilai Perusahaan Dengan Pengungkapan Corporate Social Responsibility Dan Good Corporate Governance Sebagai Variabel Pemoderasi (Studi Empiris Pada Perusahaan Manufaktur di Bursa Efek Jakarta) (Doctoral dissertation, Universitas Diponegoro).

15. Tai, F. M., \& Chuang, S. H. (2014). Corporate social responsibility. Ibusiness, 6(03), 117. 